\title{
Penjaminan Mutu dalam Pendistribusian Sediaan Farmasi
}

\author{
Nabila Mudin \\ Program Profesi Apoteker, Fakultas Farmasi, Universitas Padjadjaran, Sumedang, 45363 \\ email: awonderfulpharmacist@gmail.com
}

\begin{abstract}
Abstrak :
Sediaan farmasi merupakan salah satu bagian terpenting dalam pelayanan kesehatan. Tidak sedikit biaya yang diperlukan guna pembelanjaan sediaan farmasi. Distribusi menjadi aspek penting dalam menjamin kualitas sediaan. Untuk memastikan mutu sepanjang alur pendistribusian, maka kualitas produk perlu dipantau mulai dari produk masuk gudang hingga sampai di tangan konsumen. Sediaan farmasi sampai di tangan pasien harus dalam keadaan aman, berkhasiat, bermutu, dan terjangkau. Pengawasan obat secara komprehensif perlu dilakukan pada jaringan distribusi obat demi terjaminnya mutu, khasiat, keamanan, dan keabsahan obat. Penjaminan mutu dipantau seiring integritas rantai distribusi, mulai dari kegiatan pengadaan, penyimpanan, penyaluran hingga jika terjadi pengembalian. Pemantauan mutu mulai dari pembangunan sistem mutu (Quality Management) hingga terjadi Recall dalam proses distribusi diatur dalam Good Distribution Practice.
\end{abstract}

Keyword: Penjaminan mutu, distribusi, sediaan farmasi

\section{Outline}

- Pendahuluan

- Quality Management

- Premises, Warehousing And Storage

- Transportation and Products in Transit

- Hal-hal yang harus diperhatikan dalam proses pengiriman:

- Produk yang dikirim harus dapat dilacak selama proses distribusi

- Daftar Pustaka

\section{Pendahuluan}

Distribusi sediaan farmasi merupakan suatu kegiatan penyaluran baik obat maupun bahan obat sesuai dengan persyaratan guna menjaga kualitas dari sediaan farmasi yang didistribusikan tersebut.

Distribusi menjadi aspek penting dalam menjamin kualitas sediaan. Untuk memastikan mutu sepanjang alur pendistribusian, maka kualitas produk perlu dipantau mulai dari produk masuk gudang hingga sampai di tangan konsumen (dalam hal ini apotek, rumah sakit, PBF). 
Salah satu cara pemerintah dalam menjamin mutu sediaan farmasi adalah dengan menerapkan CDOB (Cara Distribusi Obat yang Baik). CDOB diatur dalam Peraturan Kepala BPOM No. HK.03.1.34.11.12.7542 tahun 2012.

Di Indonesia, kegiatan penyaluran obat dilakukan oleh PBF (Pedagang Besar Farmasi). PBF merupakan perusahaan berbentuk badan hukum yang memiliki izin untuk pengadaan, penyimpanan, penyaluran obat dan/atau bahan obat dalam jumlah besar sesuai ketentuan peraturan perundang-undangan (BPOM, 2012).

Distribusi merupakan kegiatan penting yang teritegrasi dengan manajemen rantai pasok sediaan farmasi. Dalam prakteknya perlu dilakukan penjaminan mutu pada semua aspek di setiap proses distribusi, mulai dari pengadaan, penyimpanan, peraturan dan registrasi distribusi hingga diberikan kepada pasien. Lemahnya system distribusi dapat membuka jalan untuk penyebaran sediaan farmasi palsu dan penjualan yang illegal (WHO, 2010).

Permasalahan yang masih terjadi di Indonesia terkait pendistribusian sediaan farmasi adalah lemahnya pengawasan pemerintah terhadap peredaran sediaan farmasi. Terbongkarnya peredaran vaksin palsu setelah 13 tahun beredar, pada 2016 merupakan salah satu bukti longgarnya pengawasan pemerintah.

Sulitnya pengadaan obat di daerah terpencil juga masih menjadi masalah yang belum dapat tertangani secara nyata. Dalam UUD 1945 Pasal $28 \mathrm{H}$ ayat (1), setiap orang berhak hidup sejahtera lahir dan batin bertempat tinggal, mendapatkan lingkungan hidup yang baik dan sehat serta berhak memperoleh pelayanan kesehatan. Setiap warga Negara Indonesia berhak memperoleh pelayanan kesehatan dan Negara wajib untuk mewujudkannya. Kurangnya kebijakan pemerintah terhadap penyebaran distributor sediaan farmasi yang di Indonesia menjadi salah satu kendala untuk pemerintah dalam melakukan pemerataan distribusi obat.

Sediaan farmasi sampai di tangan pasien harus dalam keadaan aman, berkhasiat, bermutu, dan terjangkau. Pengawasan obat secara komprehensif perlu dilakukan pada jaringan distribusi obat demi terjaminnya mutu, khasiat, keamanan, dan keabsahan obat. Penjaminan mutu dipantau seiring integritas rantai distribusi, mulai dari kegiatan pengadaan, penyimpanan, penyaluran hingga jika terjadi pengembalian. Pemantauan mutu mulai dari pembangunan system mutu (Quality Management) hingga terjadi Recall dalam proses distribusi diatur dalam Good Distribution Practice, sebagai berikut:

\section{Quality Management}

Kegiatan managemen mutu meliputi kesesuaian infrastruktur seperti organisasi, SOP, proses serta sumber daya yang digunakan dan tindakan sistematis yang diperlukan guna menjamin proses distribusi berjalan sesuai GDP (Good Distribution Practice) sehingga memenuhi persyaratan kualitas. 
Setiap aspek dalam proses distribusi sediaan farmasi harus dapat bertanggung jawab terhadap kualitas dan keamanan dari produk. Dalam pelaksanaannya, sistem yang memadai harus tersedia untuk memastikan produk dapat ditelusuri. Prosedur pengadaan dan perilisan harus dikeluarkan secara resmi, guna memastikan bahwa produk farmasi yang akan didistribusikan bersumber dari pemasok yang legal.

Semua entitas dalam proses rantai pasok harus dapat terlacak berdasarkan jenis produk farmasi tersebut dan harus dilengkapi prosedur dan catatan tertulis yang dapat menjamin ketelusuran produk. Kegiatan penjaminan mutu dalam proses distribusi meliputi managemen mutu, manajemen resiko mutu, kajian dan pemantauan manajemen serta pengelolaan kegiatan distribusi berdasarkan kontrak.

Sertifikat kesesuaian sistem mutu yang berlaku baik nasional maupun internasional (seperti International Standardization Organization (ISO)) sangat direkomendasikan untuk suatu PBF. Jika tidak memiliki sertifikat tersebut, dapat digantikan dengan guidelines pelaksanaan prinsip GMP terkait produk farmasi. SOP resmi untuk setiap kegiatan operasional harus tersedia.

Inspeksi diri adalah tindakan pencegahan terjadinya kesalahan dalam kegiatan penjaminan mutu. Inspeksi diri dilakukan sebagai tindakan korektif terhadap pelaksanaan distribusi obat berdasarkan prinsip GDP.

Inspeksi diri dilakukan oleh pihak yang independen dan kompeten. Kegiatan inspeksi diri harus selalu terdokumentasi. Laporan inspeksi diri harus berisi semua hasil observasi yang dilakukan selama kegiatan yang kemudian akan dievaluasi dan diputuskan tindakan korektif yang dapat dilakukan.

\section{Premises, Warehousing And Storage}

Good Storage Practice (GSP) harus diterapkan dalam lingkungan penyimpanan dan proses distribusi produk farmasi. Prinsip dalam penerapan GSP meliputi:

\section{Area Penyimpanan}

Area penyimpanan harus memiliki kapasitas yang cukup untuk memungkinkan penyimpanan secara berurutan dari berbagai kategori produk, yaitu produk massal dan produk jadi, produk di karantina, dan produk yang dirilis, ditolak, dikembalikan atau ditarik kembali. Area penyimpanan harus dirancang untuk memastikan kondisi penyimpanan yang baik. Area penyimpanan harus bersih dan kering dan dipelihara dalam batas suhu yang dapat diterima. Dalam kondisi penyimpanan khusus diperlukan pada label suhu dan kelembaban relatif, yang harus terus dipantau.

Produk farmasi harus disimpan di area yang mudah dibersihkan dan dilakukan pemeriksaan. Palet harus disimpan dalam kondisi yang baik dan bersih. Area penyimpanan harus bersih, dan bebas dari akumulasi limbah dan hama. Prosedur tertulis mengenai sanitasi dan pengendalian hama harus tersedia untuk menunjukkan frekuensi pelaksanaan dan metode yang digunakan. 
Agen pengendalian hama yang digunakan harus aman, dan tidak boleh ada risiko kontaminasi terhadap produk farmasi. Harus ada prosedur yang tepat untuk membersihkan tumpahan dan memastikan tidak adanya risiko kontaminasi.

Untuk produk dalam status karantina dipastikan disimpan di area terpisah, ditandai dengan jelas dan aksesnya dibatasi untuk personel yang berwenang. Setiap sistem yang menggantikan pengecekan produk karantina secara manual harus dapat menjamin keamanan. Contohnya sistem komputerisasi dapat digunakan, asalkan tervalidasi dalam keamanan akses. Jika pengambilan sampel dilakukan di area penyimpanan, harus dilakukan sedemikian rupa untuk mencegah kontaminasi. Prosedur pembersihan yang memadai harus dilakukan untuk area sampling.

Selain itu, area penyimpanan untuk produk yang ditolak, kadaluarsa, ditarik kembali atau dikembalikan harus tersedia. Produk, dan area terkait harus diidentifikasi secara tepat.

Bahan radioaktif, narkotika dan produk farmasi berbahaya lainnya, sensitif dan / atau berbahaya, serta produk yang dapat menyebabkan kebakaran, atau ledakan, harus disimpan di area khusus yang dilengkapi dengan protokol keselamatan dan keamanan tambahan yang sesuai.

\section{Kondisi Penyimpanan}

Kondisi penyimpanan untuk produk farmasi harus sesuai dengan hasil pengujian stabilitas.

\section{Monitoring Kondisi Penyimpanan}

Data pemantauan suhu yang direkap untuk ditinjau. Peralatan yang digunakan untuk pemantauan harus diperiksa pada interval yang telah ditentukan sebelumnya dan hasil dari pemeriksaan tersebut harus dicatat dan disimpan. Semua catatan pemantauan harus disimpan setidaknya selama masa simpan dari bahan yang disimpan atau produk ditambah satu tahun. Pemetaan suhu harus menunjukkan keseragaman suhu di area penyimpanan. Monittoring suhu ditempatkan di area yang paling mungkin menunjukkan fluktuasi.Peralatan yang digunakan untuk pemantauan harus dikalibrasi pada interval yang ditentukan.

\section{Dokumentasi, meliputi instruksi tertulis dan rekap data}

Informasi tertulis maupun elektronik harus ada untuk setiap produk disertai dengan kondisi penyimpanannya. Prosedur harus pemetaan suhu, keamanan gudang, penghancuran stok yang tidak dapat dijual dan penyimpanan catatan juga harus tersedia.

\section{Peputaran dan Pengendalian stock}

Rekonsiliasi stok secara periodic dilakukan untuk membandingkan stok secara actual dan stok yang terekap sebelumnya 
Perbedaan yang signifikan harus diinvestigasi sebagai tindakan pencegahan terhadap kemungkinan terjadinya mix up dan/ pendataan yang salah.

\section{Transportation and Products in Transit}

Kondisi penyimpanan yang dipersyaratkan untuk produk farmasi harus selalu dijaga bahkan saat proses pengiriman. Kondisi penyimpanan yang spesifik untuk produk tertentu sebaiknya tidak memakan waktu yang terlampau lama. Semua penyimpangan terkait kondisi penyimpanan harus dikonsultasikan dengan pihak manufacturer.

\section{Hal-hal yang harus diperhatikan dalam proses pengiriman:}

Kondisi khusus yang diperlukan produk selama proses pengiriman harus dipantau dan dicatat.

Proses pengiriman tidak boleh memberikan efek negative terhadap integritas dan kualitas dari sediaan farmasi

Prosedur tertulis harus disertai selama proses untuk dilakukan investigasi terhadap segala penyimpangan terkait kondisi penyimpanan, contohnya jika suhu tempat penyimpanan produk saat proses pengiriman tidak sesuai.

\section{Produk yang dikirim harus dapat dilacak selama proses distribusi}

Semua produk farmasi harus disimpan dan didistribusikan dalam wadah yang tidak memberikan efek buruk terhadap kualitas produk, dan memberikan perlindungan memadai dari pengaruh eksternal, termasuk kontaminasi mikroba. Label yang ditempelkan di wadah harus jelas, tidak ambigu, secara permanen tertuju pada wadah dan tidak mudah terhapuskan. Informasi tentang label harus sesuai dengan produk.

Produk yang mengandung dari bahan aktif dan radioaktif obat dan bahan berbahaya lainnya yang memberikan risiko penyalahgunaan, kebakaran, atau ledakan (misalnya, cairan yang mudah terbakar, padatan dan gas bertekanan) harus disimpan dan diangkut di dalam wadah yang aman.

Dispatch

Produk farmasi hanya boleh dijual dan didistribusikan kepada pihak yang berhak. Bukti otoritas tertulis harus diperoleh sebelum dilakukan pengiriman ke pihak tersebut. Pemasok produk farmasi harus dipastikan sebelum dilakukan pengiriman, dipastikan personil yang menyetujui kontrak terkait pengiriman dan penyimpanan produk. Pengiriman dan pengantaran produk farmasi dilakukan setelah diterimanya permintaan pengiriman material, jika ada rencana penambahan harus terdokumentasi.

Rekap data pengiriman produk farmasi harus memuat informasi sebagai berikut:

\section{Waktu pengiriman}

Nama dan alamat yang bertanggung jawab untuk pengiriman

Nama, alamat, status instansi seperti retail farmasi, rumah sakit dan komunitas klinik 
Deskripsi produk meliputi nama, bentuk dan kekuatan sediaan Jumlah produk, seperti jumlah container dan jumlah produk per container No batch dan tanggal kadaluarsa Kondisi transportasi dan penyimpanan Nomor unik untuk memungkinkan identifikasi pesanan pengiriman. Recall

Sistem dan prosedur tertulis diperlukan untuk mendeteksi secara cepat dan efektif produk farmasi yang diketahui atau diduga cacat, dengan personil yang bertanggung jawab untuk melakukan recall.

Pihak manufaktur juga harus diberi tahu jika dilakukan recall. Jika penarikan kembali dilakukan oleh entitas selain produsen asli dan / atau pemegang otorisasi pemasaran, konsultasi dengan produsen asli dan / atau pemegang otorisasi pemasaran harus dilakukan, jika memungkinkan, dilakukan sebelum dilaksanakan recall. Semua pelanggan dan otoritas terkait harus segera diberitahu jika dilakukan recall mengingat mutu dari produk tersebut.

Semua produk farmasi yang ditarik harus disimpan di area terpisah yang aman untuk menunggu tindakan yang tepat. Kondisi penyimpanan yang sesuai untuk produk farmasi yang ditarik kembali harus dipertahankan selama penyimpanan sampai saat keputusan telah dibuat terkait produk tersebut.

Dokumentasi harus tersedia untuk personil yang ditunjuk bertanggung jawab atas penarikan kembali. Dokumen harus memuat informasi yang cukup tentang produk farmasi yang diberikan kepada pelanggan (termasuk jika produk diekspor). Proses recall harus dicatat dan laporan akhir dikeluarkan, mencakup rekonsiliasi antara jumlah produk yang dikirim dan yang diperoleh kembali.

\section{Datar pustaka :}

Peraturan Kepala Badan Pengawas Obat dan Makanan Nomor HK.03.1.34.11.12.7542 tahun 2012 tentang Pedoman Teknis Cara Distribusi Obat yang Baik

UUD 1945 Pasal $28 \mathrm{H}$ ayat (1), Tersedia Online http://jdih.pom.go.id/uud1945.pdf [Diakses 04 April 2018]

WHO. 2010. Good Distribution Practices (GDP) For Pharmaceutical Products. WHO Technical Report Series, No. 957, Annex 5 